\title{
Đánh giá độc tính bán trường diễn của bột sinh khối nấm Thượing Hoàng thu được từ lên men chìm
}

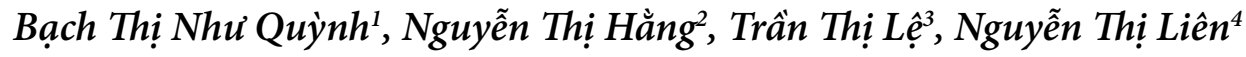 \\ Phạm Đức Cường ${ }^{5}$ Nguyễn Thị Minh Huyền ${ }^{2,6^{*}}$
}

${ }^{1}$ Truờng Đại học Y Dược Hải Phòng ${ }^{2}$ Học viện Khoa học và Công nghệ, Viện Hàn lâm Khoa học và Công nghệ Việt Nam

${ }^{3}$ Truờng dại học Khoa học Tự nhiên, Đại học Quốc gia Hà Nội

${ }^{4}$ Viện Kiêm nghiệm thuốc Trung Uơng

${ }^{5}$ Viện công nghệ HaUI, Đại học Công nghiệp Hà Nội ${ }^{6}$ Viện Công nghệ sinh học, Viện Hàn lâm Khoa học và Công nghệ Việt Nam

(Ngày đến tòa soạn: 22/8/2020; Ngày chấp nhận đăng: 30/9/2020)

\section{Tóm tắt}

Bột sinh khối (SK) nấm Thượng Hoàng $(\mathrm{TH})$ thu sau khi lên men chìm được kiểm tra độc tính bán trường diễn trên thỏ thí nghiệm nhằm mục đích đánh giá sự an toàn khi sử dụng bột như thực phẩm chức năng. Thỏ được uống hỗn dịch mẫu thử chứa bột nấm $\mathrm{TH}$ liên tục trong 28 ngày với 2 mức liều khác nhau là $0,558 \mathrm{~g} / \mathrm{kg}$ thỏ/ngày và $2,792 \mathrm{~g} / \mathrm{kg}$ thỏ/ngày. Kết quả các mẫu thử không ảnh hưởng đến cân nặng, thể trạng, hoạt động của thỏ thử nghiệm. Các chỉ số sinh hóa đánh giá chức năng gan, thận không có sự khác biệt có ý nghĩa ở trước thí nghiệm, sau 14 ngày, sau 28 ngày uống mẫu thử, cũng như sau 14 ngày dừng uống mẫu thử trong các nhóm thử nghiệm. Kết quả tương tự cũng nhận được ở các chỉ số huyết học. Không có bất thường ở các tổ chức tim, gan, thận, phổi, lách và hệ tiêu hóa của thỏ thử nghiệm trong khi quan sát đại thể cũng như không thấy tổn thương mô bệnh học của gan, thận trong khi quan sát vi thể giữa các nhóm trong thí nghiệm.

Từ khóa: Nấm Thượng hoàng, bột sinh khối, độc tính bán trường diễn, lên men chim.

\section{1. ĐĂT VẤN ĐỀ}

Nấm Thượng hoàng $(\mathrm{TH})$ có tên khoa học là Phellinus linteus, họ Hymenochaetaceae, chi Phellinus. Tổng sản lượng của các loài Phellinus trên thế giới khoảng 30 tấn/năm. Nấm Thượng Hoàng có nhiều đặc tính quý như nấm có các tác dụng điều hòa miễn dịch [1-2]; kháng viêm [3-4], kháng ung thư [5-6] và kháng oxy hóa [7]. Đây là các loài nấm mọc nhiêu năm, lớp thụ tầng năm sau chông lên lớp thụ tầng năm trước. Nấm TH mọc ở những vùng rừng sâu, núi cao hiểm trở, các khu rừng nguyên sinh, tuổi nấm có khi đến vài chục năm. Do nguôn nguyên liệu tự nhiên đã cạn kiệt bởi vì bị khai thác quá mức, hiện nay nhiều nơi đã chủ động trồng hoặc sản xuất các loại nguyên liệu để phục vụ, nâng cao sức khỏe của con người. Trước đây, việc nhân nuôi sinh khối nấm $\mathrm{TH}$ cũng như các loại nấm sợi khác được tiến hành trên thân gỗ và các giá thể. Việc nuôi trông nấm sợi trên thân gỗ và các giá thể mất rất nhiều công sức và đặc biệt là 
thời gian. Hiện nay, với sự phát triển của công nghệ lên men, đã có thể nuôi trông nấm hoàn toàn ở môi trường lỏng do ưu thế rút ngắn về thời gian và chủ động được quy mô sản xuất [79]. Trong nghiên cứu này, sinh khối (SK) nấm $\mathrm{TH}$ được tạo ra bằng cách lên men chìm. Đây là phương pháp cho hiệu quả cao do chủ động ở các khâu nhân giống và môi trường, khí hậu được điều chỉnh thích hợp cho sự phát triển của nấm. Sau khi lên men chìm, SK nấm được đông khô, nghiền thành bột và được thử nghiệm để kiểm tra độ an toàn. Nghiên cứu của chúng tôi đã thực hiện về độc tính cấp trên chuột Swiss cho thấy $\mathrm{SK}$ nấm $\mathrm{TH}$ có độc tính thấp dưới ngưỡng phân loại GHS và không gây ngộ độc cho động vật thực nghiệm (không thể hiện ở đây).

Trong nghiên cứu này, độc tính bán trường diễn trên thỏ được xác định theo quy trình chuẩn dùng trong xác định độc tính của Viện Kiểm nghiệm thuốc Trung ương. Mục đích của nghiên cứu này là đánh giá độ an toàn của sản phẩm SK nấm $\mathrm{TH}$ đã được trông theo phương pháp lên men chìm trong phòng thí nghiệm, nhằm tiến tới sử dụng như nguồn nguyên liệu thay thế nấm $\mathrm{TH}$ tự nhiên để dùng làm thực phẩm bảo vệ sức khoẻ.

\section{VÂTT LIÊUU VÀ PHƯƠNG PHÁP NGHIÊN CƯU}

\subsection{Vật liệu nghiên cứu}

Bột $\mathrm{SK}$ nấm $\mathrm{TH}$ thu được từ lên men chìm được cung cấp bởi Viện Công nghệ sinh học, Viện Hàn lâm Khoa học và Công nghệ Việt Nam. Bột nấm được ngâm nước nóng trong 15 phút và thu hỗn dịch thử với hàm lượng $0,3 \mathrm{~g}$ mẫu thử $/ \mathrm{mL}$.

Động vật thí nghiệm: 21 con thỏ Newzealand trưởng thành cả hai giống đực và cái, khỏe mạnh, thỏ cái không mang thai hoặc cho con bú, chưa trải qua bất kỳ thử nghiệm nào trước đó, cân nặng khoảng 1,8 - 2,2 kg. Thỏ được cung cấp bởi Bộ phận chăn nuôi, Viện Kiểm nghiệm thuốc Trung Ương. Tất cả các thao tác trên động vật thí nghiệm đều được tuân theo các quy trình về chăm sóc và sử dụng động vật thí nghiệm của Khoa Dược lý - Viện Kiểm nghiệm thuốc Trung Ương. Thỏ được nuôi mỗi con một lồng trong phòng nuôi có kiểm soát nhiệt độ và độ ẩm thích hợp với thức ăn và nước uống theo nhu cầu.

\subsection{Phương pháp nghiên cứu}

Phương pháp thử nghiệm và đánh giá dựa trên tham khảo tài liệu về phương pháp xác định độc tính của thuốc [10] và hướng dẫn của Tổ chức hợp tác và phát triển kinh tế cho các thử nghiệm về hóa học (OECD guidelines for testing of chemicals [11]) như sau:

\subsubsection{Chuân bị mẫu thư}

Lựa chọn mức liều thử nghiệm: Dựa trên liều tối đa dự kiến dùng trên người là $9 \mathrm{~g}$ bột SK/ người/ngày (ngày uống 3 lần, mỗi lần $3 \mathrm{~g}$ ) và sử dụng hệ số chuyển đổi liêuu giữa thỏ và người là 3,1 để lựa chọn 2 mức liều thử nghiệm sau đây:

+ Liều tương ứng với mức liêu dự kiến cho người (T1): 0,558 g/kg thỏ/ngày.

+ Liều cao gấp 5 lần liều dự kiến cho người (T2): 2,792 g/kg thỏ/ngày.

Cách xử lý và chuẩn bị mẫu thử: Mẫu đối chứng $(\mathrm{C})$ được dùng là nước; Liều cao gấp 5 liêu dự kiến cho người: Cân $67 \mathrm{~g}$ mẫu thử ngâm trong $240 \mathrm{~mL}$ nước sôi trong khoảng 15 phút, loại bỏ bã thu lấy phân hỗn dịch (hỗn dịch $\mathrm{A}$ ); Liều tương ứng với liều dự kiến cho người: Pha loãng $40 \mathrm{ml}$ hỗn dịch $\mathrm{A}$ với nước vừa đủ $160 \mathrm{~mL}$ (hỗn dịch $\mathrm{B}$ ). 


\subsubsection{Bố trí thí nghiệm}

Thí nghiệm được tiến hành trên 21 con thỏ, chia thành 03 nhóm, mỗi nhóm 07 con, kết quả được trình bày tại Bảng 1 .

Bảng 1. Các múc liêu thử nghiệm trên thỏ

\begin{tabular}{cccc} 
Nhóm & $\begin{array}{c}\text { Số thỏ thí nghiệm } \\
(\text { con })\end{array}$ & $\begin{array}{c}\text { Thể tích cho uống } \\
(\mathbf{m L} / \mathbf{k g} \text { thỏ })\end{array}$ & $\begin{array}{c}\text { Liều dùng } \\
(\mathbf{g} \text { mẫu thử/kg thỏ/ngày })\end{array}$ \\
\hline Chû́ng (C) & 07 & $10,0 \mathrm{~mL} \mathrm{nước/kg} \mathrm{thỏ}$ & --- \\
Thử 1 (T1) & 07 & $10,0 \mathrm{~mL}$ hỗn dịch B/kg thỏ & 0,558 \\
Thử 2 (T2) & 07 & $10,0 \mathrm{~mL}$ hỗn dịch $\mathrm{A} / \mathrm{kg}$ thỏ & 2,792 \\
\hline
\end{tabular}

\subsubsection{Theo dõi và đánh giá}

Theo dõi thỏ hàng ngày về mức độ tiêu thụ thức ăn, nước uống, thể trạng và vận động, tình trạng phân, nước tiểu, các biểu hiện bất thường (nếu có) của thỏ; Xác định cân nặng của thỏ tại các thời điểm $0,7,14,21,28$ ngày uống mẫu thử và 14 ngày sau khi dừng uống mẫu thử; Xét nghiệm các chỉ số huyết học liên quan tới chức năng tạo máu (số lượng hồng cầu, bạch câu, tiểu cầu, hemoglobin, hematocrit), chức năng gan (AST, ALT, protein toàn phần, bilirubin toàn phần, cholesterol), thận (creatinin, urea), chỉ số glucose tại các thời điểm $0,14,28$ ngày uống mẫu thử và 14 ngày sau khi dừng uống mẫu thử. So sánh kết quả của nhóm thử và nhóm chứng theo phương pháp thống kê.

Sau thử nghiệm động vật được mổ để quan sát đại thể các tổ chức tim, gan, thận, phổi, dạ dày, ruột của tất cả các con thỏ. Lấy ngẫu nhiên 03 con thỏ/nhóm, tiến hành làm tiêu bản giải phẫu mô bệnh học gan, thận để đánh giá vi thể các tổ chức trên ngay sau khi dừng uống mẫu thử. Tiêu bản gan, thận được cố định bằng Formalin $10 \%$, nhuộm bằng dung dịch nhuộm Hematoxylin eosin $(\mathrm{HE})$ và Perioric acid Shiff $(\mathrm{PAS})$ và quan sát dưới kính hiển vi quang học. Thí nghiệm quan sát vi thể do Bộ môn Giải phẫu sinh lý bệnh- Trường Đại học $\mathrm{Y}$ Hà Nội thực hiện

\subsubsection{Trinh bày và xủ lý số liệu}

Số liệu thực nghiệm được trình bày dưới dạng giá trị trung bình cộng trừ độ lệch chuẩn (mean $\pm \mathrm{SD}$ ) và được xử lý thống kê bằng chuẩn thống kê Student để so sánh sự khác nhau của cùng một chỉ số giữa nhóm chứng và nhóm thử.

\section{KẾT QUẢ VÀ BÀN LUẬN}

\subsection{Tình trạng thỏ}

Tất cả các thỏ đều hoạt động bình thường, ăn uống tốt, mắt sáng, lông mượt, phân khô; Thỏ tăng cân đều ở tất cả các nhóm thí nghiệm và nhóm chứng trong thời gian thí nghiệm cũng như sau khi kết thúc thử nghiệm 14 ngày (Bảng 2). 
Bảng 2. Kết quả theo dõi cân nặng của thỏ ở các giai đoạn nghiên cứu

\begin{tabular}{|c|c|c|c|c|c|c|}
\hline & \multicolumn{5}{|c|}{ Cân nặng $(k g)$ trong thời gian uống mẫu thử $(n=7)$} & \multirow{2}{*}{$\begin{array}{c}\text { Cân nặng }(\mathrm{kg}) \text { sau } \\
14 \text { ngày ngùing uống } \\
\text { mẫu thử }(n=4)\end{array}$} \\
\hline & $\begin{array}{c}\text { TrướcTN } \\
\left(m_{0}\right)\end{array}$ & $\begin{array}{c}\text { Sau } 7 \text { ngày } \\
\left(m_{1}\right)\end{array}$ & $\begin{array}{c}\text { Sau } 14 \text { ngày } \\
\left(m_{2}\right)\end{array}$ & $\begin{array}{c}\text { Sau } 21 \text { ngày } \\
\left(m_{3}\right)\end{array}$ & $\begin{array}{c}\text { Sau } 28 \text { ngày } \\
\left(m_{4}\right)\end{array}$ & \\
\hline Nhóm C & $1,98 \pm 0,18$ & $2,15 \pm 0,21$ & $2,29 \pm 0,19$ & $2,40 \pm 0,25$ & $2,44 \pm 0,18$ & $2,46 \pm 0,20$ \\
\hline $\begin{array}{l}\text { \% so với } \\
\text { trước TN }\end{array}$ & & $108,6 \%$ & $115,7 \%$ & $121,4 \%$ & $123,2 \%$ & $124,2 \%$ \\
\hline Nhóm T1 & $2,03 \pm 0,18$ & $2,24 \pm 0,19$ & $2,37 \pm 0,17$ & $2,47 \pm 0,13$ & $2,52 \pm 0,17$ & $2,70 \pm 0,16$ \\
\hline $\begin{array}{l}\text { \% so với } \\
\text { trước TN }\end{array}$ & & $110,3 \%$ & $116,7 \%$ & $121,7 \%$ & $124,1 \%$ & $133,0 \%$ \\
\hline Nhóm T2 & $2,00 \pm 0,15$ & $2,22 \pm 0,11$ & $2,30 \pm 0,08$ & $2,40 \pm 0,09$ & $2,48 \pm 0,10$ & $2,56 \pm 0,07$ \\
\hline $\begin{array}{l}\text { \% so với } \\
\text { trước TN }\end{array}$ & & $111,0 \%$ & $115,0 \%$ & $120,0 \%$ & $124,0 \%$ & $128,0 \%$ \\
\hline
\end{tabular}

Cân nặng trung bình của thỏ ở các nhóm thử trước khi đưa vào thí nghiệm không có sự khác biệt so với nhóm chứng $\left(\mathrm{P}_{\text {trước(T1-C) }}>0,05 ; \mathrm{P}_{\text {trước(T2-C) }}>0,05\right)$. Sau 28 ngày uống mẫu thử, thỏ ở nhóm chứng và hai nhóm thử đều tăng cân ở mỗi thời điểm đánh giá. Có sự khác biệt có ý nghĩa về cân nặng khi so sánh sau 28 ngày thử nghiệm với trước thử nghiệm trong mỗi nhóm $\left(\mathrm{P}_{\text {trước- sau }}<0,05\right)$. Không có sự khác biệt có ý nghĩa về cân nặng trung bình giữa nhóm thử so với nhóm chứng $\left(\mathrm{P}_{\text {sau(T1-C) }}>0,05 ; \mathrm{P}_{\text {sau(T2-C) }}>0,05\right)$. Sau 14 ngày ngừng uống mẫu thử: thỏ khỏe mạnh tăng cân tốt, không có sự khác biệt có ý nghĩa thống kê về cân nặng trung bình giữa hai nhóm thử so với nhóm chứng $\left(\mathrm{P}_{\mathrm{sau}(\mathrm{T1}-\mathrm{C})}>0,05 ; \mathrm{P}_{\mathrm{sau}(\mathrm{T} 2-\mathrm{C})}>0,05\right)$ (Bảng 2).

\subsection{Các chỉ số huyết học liên quan tới chức năng tạo máu, sinh hóa liên quan tới chức năng gan, thận và chỉ số glucose trong huyết tương}

Các chỉ số huyết học liên quan tới chức năng tạo máu được sử dụng để đánh giá tổng quan tình trạng sức khỏe và các bệnh lý liên quan đến hệ tạo máu như thiếu máu, bệnh lý về tủy xương hoặc một số bệnh viêm nhiễm khác được tổng hợp tại Bảng 3.

Bảng 3. Kết quả xét nghiệm các chỉ số huyết học truớc và sau nghiên cưuu

\begin{tabular}{|c|c|c|c|c|c|c|}
\hline $\begin{array}{c}\text { Thời } \\
\text { diểm xét } \\
\text { nghiệm }\end{array}$ & Chỉ tiêu & Nhóm C & Nhóm T1 & $\boldsymbol{P}_{(T 1-C)}$ & Nhóm T2 & $\boldsymbol{P}_{(T 2-C)}$ \\
\hline \multirow{5}{*}{$\begin{array}{l}\text { Trước khi } \\
\text { uống mẫu } \\
\text { thư }(n=7)\end{array}$} & Hồng cầu (× 10²/ L) & $5,6 \pm 0,3$ & $6,0 \pm 0,5$ & $>0,05$ & $6,0 \pm 0,3$ & $>0,05$ \\
\hline & Bạch cầu $\left(\times 10^{9} / \mathrm{L}\right)$ & $6,0 \pm 1,7$ & $6,5 \pm 1,4$ & $>0,05$ & $6,4 \pm 1,1$ & $>0,05$ \\
\hline & Tiểu cầu $\left(\times 10^{9} / \mathrm{L}\right)$ & $352,9 \pm 76,0$ & $387,6 \pm 57,6$ & $>0,05$ & $343,0 \pm 80,5$ & $>0,05$ \\
\hline & Hematocrit (\%) & $39,7 \pm 1,6$ & $41,3 \pm 2,7$ & $>0,05$ & $40,8 \pm 2,1$ & $>0,05$ \\
\hline & Hemoglobin (g/dL) & $12,1 \pm 0,6$ & $12,6 \pm 0,9$ & $>0,05$ & $12,5 \pm 0,5$ & $>0,05$ \\
\hline
\end{tabular}




\begin{tabular}{|c|c|c|c|c|c|c|}
\hline \multirow{5}{*}{$\begin{array}{c}\text { Sau } 14 \\
\text { ngày uống } \\
\text { mấu thứ } \\
(n=7)\end{array}$} & Hồng cầu $\left(\times 10^{12} / \mathrm{L}\right)$ & $5,6 \pm 0,5$ & $5,7 \pm 0,3$ & $>0,05$ & $5,8 \pm 0,4$ & $>0,05$ \\
\hline & Bạch câu (× 109\% L) & $6,1 \pm 1,0$ & $7,0 \pm 1,4$ & $>0,05$ & $6,9 \pm 1,6$ & $>0,05$ \\
\hline & Tiểu câu (× 10²/ L) & $445,1 \pm 88,0$ & $412,1 \pm 70,1$ & $>0,05$ & $417,7 \pm 34,7$ & $>0,05$ \\
\hline & Hematocrit (\%) & $40,0 \pm 04,1$ & $41,2 \pm 1,6$ & $>0,05$ & $41,5 \pm 2,1$ & $>0,05$ \\
\hline & Hemoglobin (g/dL) & $12,0 \pm 0,8$ & $12,3 \pm 0,5$ & $>0,05$ & $12,5 \pm 0,5$ & $>0,05$ \\
\hline \multirow{5}{*}{$\begin{array}{c}\text { Sau } 28 \\
\text { ngày uống } \\
\text { mấu thử } \\
(n=7)\end{array}$} & Hồng cầu $\left(\times 10^{12} / \mathrm{L}\right)$ & $5,5 \pm 0,4$ & $6,0 \pm 0,3$ & $>0,05$ & $5,9 \pm 0,3$ & $>0,05$ \\
\hline & Bạch câu (× 10% L) & $8,4 \pm 1,2$ & $7,8 \pm 1,1$ & $>0,05$ & $9,4 \pm 2,2$ & $>0,05$ \\
\hline & Tiểu cầu $\left(\times 10^{9} / \mathrm{L}\right)$ & $507,1 \pm 60,3$ & $458,1 \pm 64,8$ & $>0,05$ & $485,4 \pm 64,7$ & $>0,05$ \\
\hline & Hematocrit (\%) & $40,2 \pm 3,2$ & $42,8 \pm 1,8$ & $>0,05$ & $41,5 \pm 1,3$ & $>0,05$ \\
\hline & Hemoglobin (g/dL) & $12,6 \pm 0,9$ & $13,5 \pm 0,6$ & $>0,05$ & $13,1 \pm 0,5$ & $>0,05$ \\
\hline \multirow{5}{*}{$\begin{array}{c}\text { Sau } 14 \\
\text { ngày düng } \\
\text { uống } \\
\text { mấu thü } \\
(n=4)\end{array}$} & Hồng cầu $\left(\times 10^{12} / \mathrm{L}\right)$ & $6,2 \pm 0,3$ & $6,6 \pm 0,4$ & $>0,05$ & $6,3 \pm 0,2$ & $>0,05$ \\
\hline & Bạch câu (× 109\% L) & $7,9 \pm 1,1$ & $9,1 \pm 0,5$ & $>0,05$ & $9,9 \pm 1,5$ & $>0,05$ \\
\hline & Tiểu câu $\left(\times 10^{9} / \mathrm{L}\right)$ & $435,8 \pm 112,1$ & $401,8 \pm 60,5$ & $>0,05$ & $379,3 \pm 64,7$ & $>0,05$ \\
\hline & Hematocrit (\%) & $44,3 \pm 3,7$ & $45,2 \pm 3,0$ & $>0,05$ & $43,8 \pm 2,0$ & $>0,05$ \\
\hline & Hemoglobin (g/dL) & $14,0 \pm 0,9$ & $14,4 \pm 0,9$ & $>0,05$ & $13,6 \pm 0,9$ & $>0,05$ \\
\hline
\end{tabular}

Các chỉ số sinh hóa liên quan đến chức năng gan như AST, ALT, bilirubin toàn phân, protein toàn phần, cholesterol được tổng hợp ở Bảng 4.

Bảng 4. Kết quả xét nghiệm các chỉ số liên quan đến chức năng gan trước và sau nghiên cứu

\begin{tabular}{|c|c|c|c|c|c|c|}
\hline $\begin{array}{c}\text { Thời điểm } \\
\text { xét nghiệm }\end{array}$ & Chỉ tiêu & Nhóm C & Nhóm T1 & $\boldsymbol{P}_{(T 1-C)}$ & Nhóm T2 & $P_{(T 2-C)}$ \\
\hline \multirow{5}{*}{$\begin{array}{c}\text { Trước khi } \\
\text { uống mẫu } \\
\text { thử } \\
(n=7)\end{array}$} & $\operatorname{AST}(\mathrm{U} / \mathrm{L})$ & $45,1 \pm 21,9$ & $65,5 \pm 22,0$ & $>0,05$ & $70,9 \pm 32,9$ & $>0,05$ \\
\hline & $\operatorname{ALT}(\mathrm{U} / \mathrm{L})$ & $76,6 \pm 28,5$ & $88,1 \pm 23,8$ & $>0,05$ & $93,0 \pm 44,9$ & $>0,05$ \\
\hline & Bilirubin toàn phần $(\mu \mathrm{mol} / \mathrm{L})$ & $3,7 \pm 1,5$ & $5,5 \pm 2,5$ & $>0,05$ & $3,7 \pm 1,9$ & $>0,05$ \\
\hline & Protein toàn phân $(\mathrm{g} / \mathrm{L})$ & $54,1 \pm 3,7$ & $57,1 \pm 4,5$ & $>0,05$ & $55,0 \pm 2,1$ & $>0,05$ \\
\hline & Cholesterol (mmol/ L) & $2,1 \pm 0,7$ & $2,7 \pm 1,5$ & $>0,05$ & $2,5 \pm 0,8$ & $>0,05$ \\
\hline \multirow{5}{*}{$\begin{array}{c}\text { Sau } 14 \text { ngày } \\
\text { uống mẫu } \\
\text { thủ } \\
(n=7)\end{array}$} & $\operatorname{AST}(\mathrm{U} / \mathrm{L})$ & $68,6 \pm 29,2$ & $57,6 \pm 19,4$ & $>0,05$ & $58,0 \pm 19,6$ & $>0,05$ \\
\hline & $\operatorname{ALT}(\mathrm{U} / \mathrm{L})$ & $64,5 \pm 11,2$ & $77,1 \pm 18,4$ & $>0,05$ & $71,8 \pm 24,8$ & $>0,05$ \\
\hline & Bilirubin toàn phần $(\mu \mathrm{mol} / \mathrm{L})$ & $5,5 \pm 1,9$ & $5,5 \pm 1,5$ & $>0,05$ & $7,1 \pm 2,6$ & $>0,05$ \\
\hline & Protein toàn phân $(\mathrm{g} / \mathrm{L})$ & $60,5 \pm 2,9$ & $60,2 \pm 1,7$ & $>0,05$ & $60,4 \pm 1,3$ & $>0,05$ \\
\hline & Cholesterol $(\mathrm{mmol} / \mathrm{L})$ & $2,0 \pm 0,3$ & $1,9 \pm 0,5$ & $>0,05$ & $2,2 \pm 0,7$ & $>0,05$ \\
\hline \multirow{5}{*}{$\begin{array}{c}\text { Sau } 28 \text { ngày } \\
\text { uống mẫu } \\
\text { thử } \\
(n=7)\end{array}$} & AST (U/L) & $43,5 \pm 22,3$ & $28,0 \pm 4,3$ & $>0,05$ & $24,3 \pm 6,4$ & $>0,05$ \\
\hline & $\operatorname{ALT}(\mathrm{U} / \mathrm{L})$ & $87,5 \pm 31,0$ & $71,1 \pm 19,0$ & $>0,05$ & $67,6 \pm 18,9$ & $>0,05$ \\
\hline & Bilirubin toàn phần $(\mu \mathrm{mol} / \mathrm{L})$ & $1,6 \pm 0,2$ & $1,4 \pm 0,2$ & $>0,05$ & $1,5 \pm 0,2$ & $>0,05$ \\
\hline & Protein toàn phân $(\mathrm{g} / \mathrm{L})$ & $62,8 \pm 1,7$ & $61,1 \pm 1,5$ & $>0,05$ & $60,8 \pm 1,7$ & $>0,05$ \\
\hline & Cholesterol (mmol/ L) & $1,8 \pm 0,8$ & $1,7 \pm 0,8$ & $>0,05$ & $2,0 \pm 0,7$ & $>0,05$ \\
\hline
\end{tabular}




\begin{tabular}{ccccccc}
\hline & AST $(\mathrm{U} / \mathrm{L})$ & $36,7 \pm 16,7$ & $39,4 \pm 18,2$ & $>0,05$ & $27,9 \pm 5,7$ & $>0,05$ \\
$\begin{array}{c}\text { Sau 14 ngày } \\
\text { dừng uống } \\
\text { mẫu thử }\end{array}$ & ALT $(\mathrm{U} / \mathrm{L})$ & $77,0 \pm 22,8$ & $79,1 \pm 29,9$ & $>0,05$ & $74,5 \pm 25,6$ & $>0,05$ \\
$(\mathbf{n}=\mathbf{4})$ & Bilirubin toàn phần $(\mu \mathrm{mol} / \mathrm{L})$ & $1,2 \pm 0,3$ & $1,4 \pm 0,7$ & $>0,05$ & $1,4 \pm 0,4$ & $>0,05$ \\
& Protein toàn phần $(\mathrm{g} / \mathrm{L})$ & $61,4 \pm 2,8$ & $57,7 \pm 2,2$ & $>0,05$ & $57,6 \pm 1,5$ & $>0,05$ \\
& Cholesterol $(\mathrm{mmol} / \mathrm{L})$ & $2,1 \pm 0,8$ & $1,9 \pm 0,9$ & $>0,05$ & $2,5 \pm 0,7$ & $>0,05$ \\
\hline
\end{tabular}

Các chỉ số Urea và Creatinin thường được xét nghiệm để theo dõi chức năng thận, được tổng hợp tại Bảng 5. Urea là một trong những sản phẩm sau khi chuyển hóa chất đạm trong cơ thể. Creatinin là sản phẩm của sự thoái hóa creatin trong các cơ. Urea và creatinin được đào thải qua thận. Khi nồng độ của urea và creatinin tăng cao cho thấy sự rối loạn chức năng thận do thận đã bị suy giảm khả năng lọc và đào thải hai chất này.

Bảng 5. Kết quả xét nghiệm các chỉ số liên quan đến chức năng thận trước và sau nghiên cứu

\begin{tabular}{|c|c|c|c|c|}
\hline Thời điểm xét nghiệm & Chỉ tiêu & Nhóm C & Nhóm T1 & Nhóm T2 \\
\hline \multirow{2}{*}{ Trước khi uống mẫu thử $(n=7)$} & Urea $(\mathrm{mmol} / \mathrm{L})$ & $5,1 \pm 1,2$ & $4,8 \pm 1,0$ & $5,1 \pm 1,1$ \\
\hline & Creatinin $(\mu \mathrm{mol} / \mathrm{L})$ & $81,2 \pm 8,0$ & $80,1 \pm 9,4$ & $84,8 \pm 7,2$ \\
\hline \multirow{2}{*}{ Sau 14 ngày uống mẫu thử $(n=7)$} & Urea $(\mathrm{mmol} / \mathrm{L})$ & $4,7 \pm 0,8$ & $4,4 \pm 0,5$ & $5,4 \pm 0,9$ \\
\hline & Creatinin $(\mu \mathrm{mol} / \mathrm{L})$ & $84,2 \pm 6,3$ & $77,9 \pm 9,8$ & $89,4 \pm 8,6$ \\
\hline \multirow{2}{*}{ Sau 28 ngày uống mẫu thủ $(n=7)$} & Urea $(\mathrm{mmol} / \mathrm{L})$ & $4,8 \pm 0,7$ & $4,6 \pm 0,6$ & $5,3 \pm 0,5$ \\
\hline & Creatinin $(\mu \mathrm{mol} / \mathrm{L})$ & $88,7 \pm 7,7$ & $89,1 \pm 8,2$ & $95,5 \pm 12,7$ \\
\hline \multirow{2}{*}{ Sau 14 ngày dùng uống mẫu thử $(n=4)$} & Urea $(\mathrm{mmol} / \mathrm{L})$ & $5,3 \pm 0,7$ & $4,8 \pm 0,5$ & $5,9 \pm 1,2$ \\
\hline & Creatinin $(\mu \mathrm{mol} / \mathrm{L})$ & $99,1 \pm 11,2$ & $93,6 \pm 20,9$ & $107,9 \pm 16,0$ \\
\hline
\end{tabular}

$$
\boldsymbol{P}_{(T 1-C)}>0,05 ; \boldsymbol{P}_{(T 2-C)}>0,05
$$

Các chỉ số urea và creatinin ở bảng 5 không có sự chênh lệch đáng kể giữa các nhóm thử và nhóm chứng ở các thời điểm trong thí nghiệm. Không có sự khác biệt có ý nghĩa thống kê của các chỉ số này so với nhóm chứng $\left(\boldsymbol{P}_{(T 1-C)}>0,05 ; \boldsymbol{P}_{(T 2-C)}>0,05\right)$.

Bảng 6. Kết quả xét nghiệm chỉ số glucose trước và sau nghiên cứu

\begin{tabular}{|c|c|c|c|}
\hline Thời điêm xét nghiệm & Nhóm C & Nhóm T1 & Nhóm T2 \\
\hline Trước khi uống mẫu thủ $(n=7)$ & $8,2 \pm 1,5$ & $7,3 \pm 1,1$ & $7,6 \pm 1,0$ \\
\hline Sau 14 ngày uống mẫu thủ $(n=7)$ & $7,8 \pm 0,6$ & $7,5 \pm 0,6$ & $7,6 \pm 0,7$ \\
\hline Sau 28 ngày uống mẫu thủ $(n=7)$ & $7,8 \pm 1,0$ & $7,4 \pm 0,5$ & $7,9 \pm 0,6$ \\
\hline Sau 14 ngày dùng uống mẫu thủ $(n=4)$ & $8,7 \pm 0,8$ & $8,1 \pm 0,7$ & $7,9 \pm 1,0$ \\
\hline
\end{tabular}

$$
\boldsymbol{P}_{(T 1-C)}>0,05 ; \boldsymbol{P}_{(T 2-C)}>0,05 \text {; đơn } v i \text { đo: } \mathrm{mmol} / \mathrm{L}
$$

Kết quả xét nghiệm các chỉ số huyết học (Bảng 3), chỉ số sinh hóa liên quan đến chức năng gan (Bảng 4), chức năng thận (Bảng 5) và chỉ số glucose (Bảng 6) đều cho thấy: Trước và sau khi uống mẫu thử ở các giai đoạn 14 ngày, 28 ngày và sau 14 ngày dừng uống: Không có sự khác biệt có ý nghĩa thống kê về các chỉ số liên quan đến các chức năng trên giữa nhóm chứng và 2 nhóm thử $\left.\left(P_{\text {truóotT (T-C) }}>0,05 ; P_{\text {sau } 14 \text { ngày (T-C) }}>0,05 ; P_{\text {sau } 28 \text { ngày (T-C) }}>0,05\right), P_{\text {sau } 14 \text { ngày dùng uống mẫu thủ }(T-C)}>0,05\right)$ 


\subsection{Quan sát đại thể và vi thể}

Quan sát đại thể: Các cơ quan nội tạng của tất cả thỏ thử nghiệm đều không có biểu hiện khác thường về hình dạng bên ngoài; cũng như màu sắc của các tổ chức tim, gan, thận, phổi, dạ dày, ruột đều bình thường ở các thỏ nhóm thử liều thấp và liêu cao so với nhóm chứng sau thí nghiệm (Hình 1).
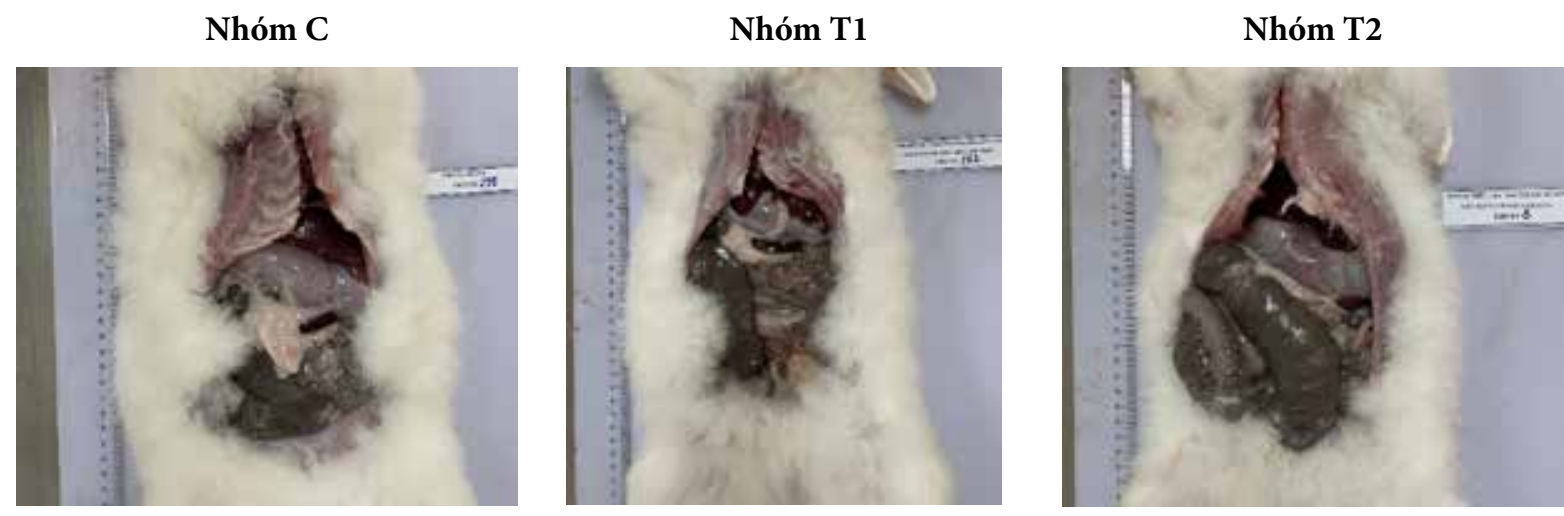

Hình 1. Hình ảnh đại thể các cơ quan nội tạng

Quan sát vi thể: Các mô bệnh học của gan và thận của thỏ được nhuộm với Hematoxylin Eosin (HE) và Periodic Acid Schiffs (PAS) và quan sát dưới kính hiển vi với độ phóng đại 400 lần. Kết quả nhuộm soi cho thấy các con thỏ thử nghiệm đều có gan, thận không bị tổn thương, hình ảnh cấu trúc trong giới hạn bình thường (Hình 2 và 3 ). Không có các triệu chứng bất thường liên quan đến mẫu thử với 2 mức liêu khác nhau so với nhóm chứng. Cụ thể: Đối với mô gan: các tế bào gan có nhân nhuộm rõ nét màu xanh tím và các thành phần ngoại bào được nhuộm màu hồng, cấu trúc đông đều; mao mạch nan hoa, khoảng cửa, mô kẽ tất cả đều bình thường, không thấy tổn thương giữa các nhóm thử và giữa nhóm thử với nhóm chứng (Hình 2). Đối với mô thận: Tiểu cầu thận (mao mạch, gian mạch, bao Baoman), ống thận, đài bể thận, Mô kẽ tất cả bình thường, không thấy tổn thương (Hình 3). Các tế bào thận nhuộm màu đông đều, nhân tế bào bắt màu xanh tím và các thành phần ngoại bào bắt màu hông hoặc màu xanh tùy theo thuốc nhuộm.
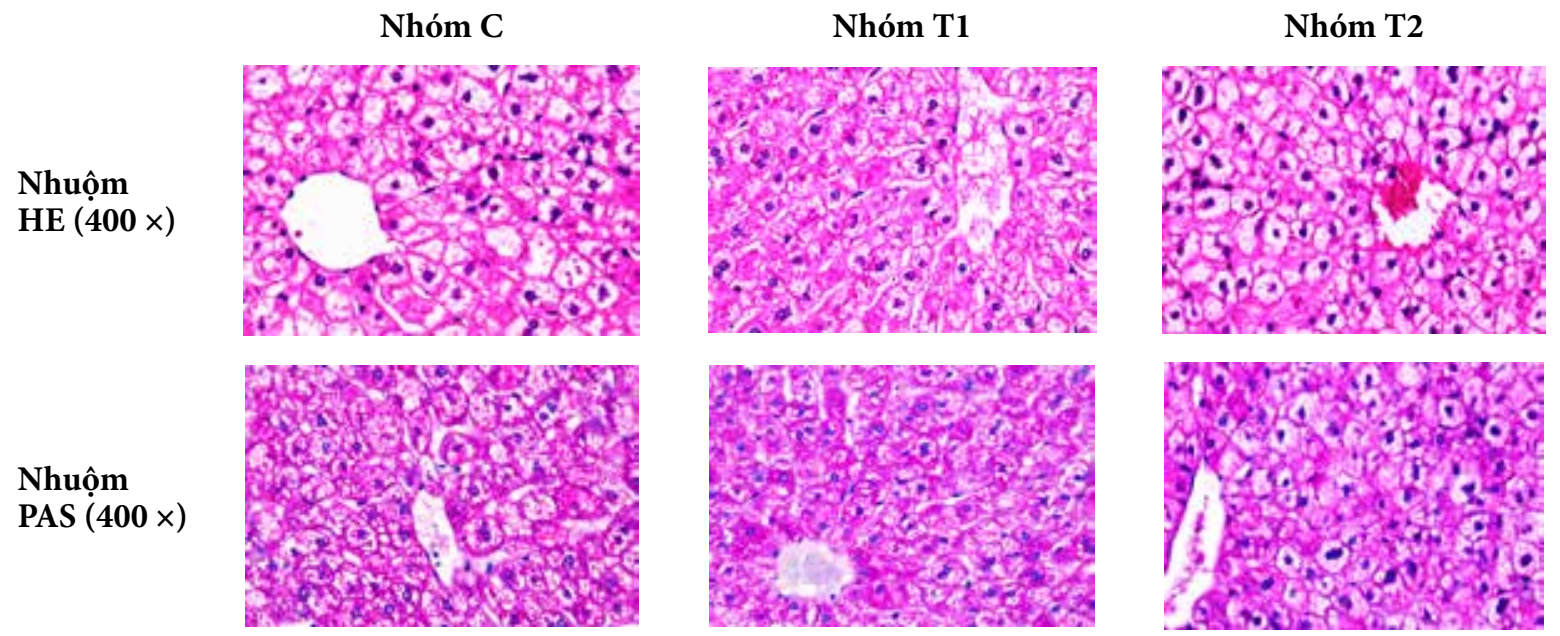

Hình 2. Hình ảnh giải phẫu mô bệnh học của gan 
Mô gan bình thường, không thấy tổn thương ở cả nhóm chứng và T1, T2. Các tế bào gan hình đa diện, nhân bắt màu xanh, bào tương bắt màu hồng, tạo thành bè, xen kẽ là mao mạch nan hoa, ở giữa là tĩnh mạch trung tâm tiểu thùy.
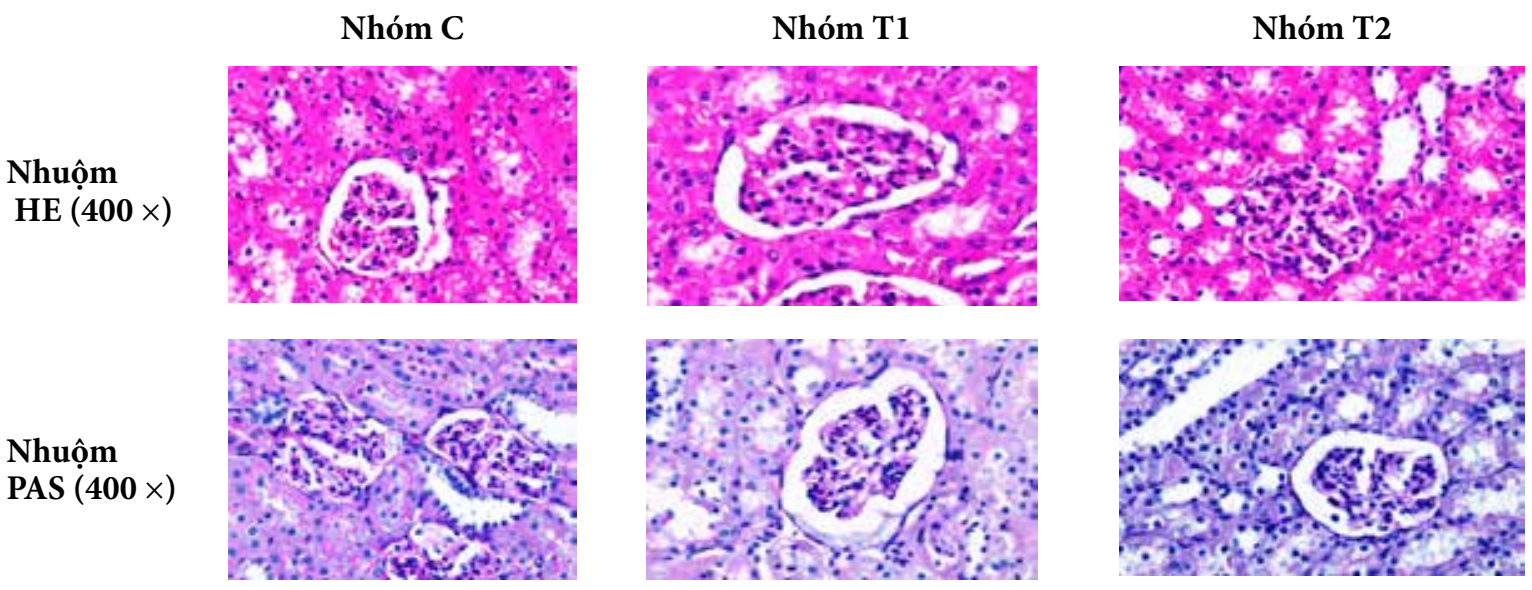

Hình 3. Hình ảnh giải phẫu mô bệnh học của thận

Mô thận bình thường, không thấy tổn thương ở cả nhóm chứng và nhóm T1, T2. Tiểu cầu thận không thấy tăng sinh gian mạch, không dính với búi mao mạch, thành không dây. Ống thận không thấy tăng sinh biểu mô, không thấy thoái hóa. Tế bào ống thận hình trụ vuông, nhân bắt màu xanh, bào tương màu hồng. Không thấy trụ niệu trong ống thận.

Kết quả quan sát đại thể và vi thể cho thấy tất cả các mô và tổ chức cơ thể được quan sát đều bình thường, không có tổn thương ở tất cả các nhóm thỏ trong thí nghiệm này. Như vậy, sau khi sử dụng bột sinh khối nấm TH không gây ra các tổn thương ở các cơ quan nội tạng của thỏ thí nghiệm ở tất cả các nhóm thí nghiệm so với nhóm chứng. Các nghiên cứu trước đây về polysaccharide của nấm TH được sử dụng ở liều $200 \mathrm{mg} / \mathrm{kg}$ trong 30 ngày không làm tăng đáng kể vể hàm lượng ALT và $A S T$ trong huyết thanh, $L P O$ trong gan và thận, hay không thể hiện độc tính của nó [12]. Nghiên cứu về độc tính cấp của dịch chiết cồn của nấm TH trong tổ hợp với một số loại nấm khác ở liều uống $1.000 \mathrm{mg} / \mathrm{kg} /$ ngày trong 14 ngày không biểu hiện bất cứ một dấu hiệu nào gây chết hoặc có độc so với nhóm đối chứng [13]. Ngoài ra có báo cáo đánh giá việc sử dụng dịch chiết cồn của nấm TH ở liều dùng $400 \mathrm{mg} / \mathrm{kg}$ trong 23 ngày đã thể hiện hiệu quả chống ung thư một cách đáng kể và không có tác dụng phụ [14]. Hiện nay ngay cả với các công bố trên thế giới vẫn còn thiếu các nghiên cứu về độc tính bán trường diễn của nấm $\mathrm{TH}$. Do đó nghiên cứu này đã đánh giá được độc tính bán trường diễn của bột SK nấm TH trên thỏ, và cũng là nghiên cứu mới về lĩnh vực này [15].

\section{KẾT LUÂN}

Sau khi cho thỏ uống hỗn dịch bột SK nấm TH liên tục trong 28 ngày với 02 mức liều khác nhau và tiếp tục theo dõi 14 ngày sau khi uống hỗn dịch thử, thỏ vẫn khỏe mạnh, hoạt động bình thường, ăn uống bình thường và tăng cân, không có khác biệt với nhóm chứng. Các chỉ số sinh hóa đánh giá chức năng gan, thận không có sự khác biệt có ý nghĩa ở trước thí nghiệm, sau 14 ngày uống mẫu thử, sau 28 ngày uống mẫu thử, và sau 14 ngày dừng uống mẫu thử giữa hai nhóm thử nghiệm so với nhóm chứng. Kết quả tương tự cũng nhận được ở các chỉ số huyết học. Không có bất thường ở các tổ chức tim, gan, thận, phổi, lách và hệ tiêu hóa của thỏ thử nghiệm trong khi quan sát đại thể cũng như không thấy tổn thương mô bệnh học của gan, thận trong khi quan sát vi thể giữa các nhóm trong thí nghiệm. 


\section{LỜI CẢM ƠN}

Để hoàn thành nghiên cứu này, chúng tôi trân trọng cảm ơn sự hỗ trợ kinh phí của Bộ Công Thương trong khuôn khổ đề tài nghiên cứu cấp nhà nước với mã số ĐT.04.18/CNSHCB.

\section{TÀI LIỆU THAM KHẢO}

[1]. H. M. Kim, S. B. Han, G. T. Oh, Y. H. Kim, D. H. Hong, N. D Hong and I. D. Yoo, "Stimulation of humoral and cell mediated immunity by polysaccharide from mushroom Phellinus linteus", International Journal of Immunopharmacology, vol. 18, no. 5, pp. 295303, 1996.

[2]. G. T. Oh, S. B. Han, H. M. Kim, M. W. Han and I. D. Yoo, "Immunostimulating activity of Phellinus linteus extracts to B-lymphocyte", Archives of Pharmacal Research, vol. 15, no. 4, pp. 379-381, 1992.

[3]. M. Song and H-J. Park, "Anti-inflammatory effect of Phellinus linteus grown on germinated brown rice on dextran sodium sulfate-induced acute colitis in mice and LPS-activated macrophages", Journal of Ethnopharmacology, vol. 154, no.2, pp. 311-318, 2014.

[4]. H-J. Park, E. S. Han, D. K. Park, C. Lee and K. W. Lee, "An extract of Phellinus linteus grown on germinated brown rice inhibits inflammation markers in RAW264.7 macrophages by suppressing inflammatory cytokines, chemokines, and mediators and up-regulating antioxidant activity", Journal of Medicinal Food, vol. 13, no. 6, pp. 1468-1477, 2010.

[5]. H. J. Park, S. Y. Choi, S. M. Hong, S. G. Hwang and D. K. Park, "The ethyl acetate extract of Phellinus linteus grown on germinated brown rice induces G0/G1 cell cycle arrest and apoptosis in human colon carcinoma HT29 cells", Phytotherapy Research, vol. 24, no. 7, pp. 1019-1026, 2010.

[6]. T-I. Jeon, C-H. Jung, J-Y. Cho, D. K. Park, and J-H. Moon, "Identification of an anticancer compound against HT-29 cells from Phellinus linteus grown on germinated brown rice", Asian Pacific Journal of Tropical Biomedicine, vol. 3, no. 10, pp. 785-789, 2013.

[7]. T. I. Jeon, S.G. Hwang, B. O. Lim and D. K. Park, "Extracts of Phellinus linteus grown on germinated brown rice suppress liver damage induced by carbon tetrachloride in rats", Biotechnology Letters, vol. 25, no. 24, pp. 2093-2096, 2003.

[8]. W-S. Jo, Y-H. Rew, S-G. Choi, G-S. Seo, J. M. Sung and J-Y. Uhm, “The Culture Conditions for the Mycelial Growth of Phellinus spp.", Mycobiology, vol. 34, no. 4, pp. 200-205, 2006.

[9]. J. W. Lee, S. J. Baek and Y. S. Kim, "Submerged Culture of Phellinus linteus for Mass Production of Polysaccharides”, Mycobiology, vol. 36, no. 3, pp. 178-182, 2008.

[10]. Phương pháp xác định độc tính của thuốc, Nhà xuất bản Y học, 2014.

[11]. OECD guidelines for testing of chemicals, Repeated dose 28 - days Oral Toxicity study in Rodents, OECD 407, 2008.

[12]. S. Zhong, D-F. Ji, Y-G. Li, T-B. Lin, Z-Q. Lv and H-P. Chen, "Activation of P27kip1-cyclin D1/E-CDK2 pathway by polysaccharide from Phellinus linteus leads to S-phase arrest in HT-29 cells", Chemmico-Biological Interaction, vol 206, no. 2, pp. 222-229, 2013.

[13]. H. J. Park, “CARI III inhibits tumor growth in a melanoma-bearing mouse model through induction of G0/G1 cell cycle arrest", Molecules, vol. 19, no. 9, pp.14383-14395, 2014. 
[14]. H. J. Park, J. B Park, S. J. Lee and M. J. Song, "Phellinus linteus grown on germinated brown rice increases cetuximab sensitivity of KRAS-mutated colon cancer", International Journal of Molecular Sciences., vol. 18, no. 8, pp.1746, 2017.

[15]. W. W. Chen, H. Tan, Q. Liu, X. Zheng, H. Zhang, Y. Liu and L. Xu, "A Review: The Bioactivities and Pharmacological Applications of Phellinus linteus", Molecules, vol. 24, no.10, pp. 1888, 2019.

\title{
Semi-chronic toxicity assessment of Phellinus linteus biomass powder from submerged-culture
}

\author{
Bach Thi Nhu Quynh ${ }^{1}$, Nguyen Thi Hang ${ }^{2}$, Tran Thi Le ${ }^{3}$, Nguyen Thi Lien ${ }^{4}$ \\ Pham Duc Cuong ${ }^{5}$, Nguyen Thi Minh Huyen ${ }^{2,6^{*}}$ \\ ${ }^{1}$ Hai Phong University Medicinal and Pharmacy, Hai Phong \\ ${ }^{2}$ Graduate University of Science and Technology, Vietnam Academy of Science and Technology, Hanoi \\ ${ }^{3}$ Natural Science University, Hanoi National University, Hanoi \\ ${ }^{4}$ National Institute of Drug Quality Control, Hanoi \\ ${ }^{5} \mathrm{HaUI}$ Technology Institute, Hanoi Industry University, Hanoi \\ ${ }^{6}$ Institute of Biotechnology, Vietnam Academy of Science and Technology, Hanoi
}

\section{Abstract}

Phellinus linteus biomass powder obtained after submerge-fermentation was assested for semi-chronic toxicity in rabbit for evaluation of the safety of using it as functional food. Rabbits were drunk test solution continuously in 28 days with 2 doses: $0.558 \mathrm{~g} / \mathrm{kg}$ rabbit/ day and 2.792 $\mathrm{g} / \mathrm{kg}$ rabbit/day. The result showed that the tested samples did not affect to weight, status, activity of tested rabbit. The biochemical index which expressed the liver, kidney functions had no statistical different at before test, after 14 days of test, after 28 days of test, and after 14 days finish of test between tested group and control group (without drink tested sample). The similarity results was obtained with hematological index. There were no abnormal occur in heart, liver, kidney, lung, spleen, and digestive system of tested rabbits in general observation as well as no histopathological lesions of the liver and kidneys in microscopic observation of tested group.

Keywords: Phellinus linteus, biomass powder, semi-chronic toxicity, submerged culture. 